\title{
SECURITIES ACT OF 1933: BUSINESS EXPERIENCE $A N D$ ACCESS TO CORPORATE RECORDS REQUIRED FOR PRIVATE OFFERING EXEMPTION
}

In Lively v. Hirschfeld' the Court of Appeals for the Tenth Circuit held that the sale of securities to offerees who possessed neither "exceptional business experience" nor regular access to corporate records did not qualify for the private offering exemption under section 4(2) of the Securities Act of $1933 .{ }^{2}$ Hirschfeld, the sole stockholder of the Wun Drop Company, sold 8,000 out of 50,000 outstanding shares of the company to one business and to approximately twenty-five individuals in four states between September 8, 1967 and April 3, 1968. No registration statement was filed with the SEC. Several of these purchasers brought suit under section 12(1) of the Securities Act of $1933,{ }^{3}$ seeking rescission of the sales on the ground that they were effected under an unregistered public offering. The district court dismissed the complaint, finding that the offerees were sophisticated and educated, and that their relationships to the defendants gave them access to such information as would have been revealed by a registration statement. The court also found no evidence that the defendants withheld from the offerees any information which, if learned, would have caused an experienced investor to reject the offer. ${ }^{4}$ The court of appeals, holding that the buyers were neither sufficiently experienced in business affairs nor adequately informed of the company's financial status, rendered judgment for the plaintiffs. ${ }^{5}$

1. 440 F.2d 631 (10th Cir. 1971), rev'g 308 F. Supp. 612 (D. Colo. 1970).

2. 15 U.S.C. \& 77d(2) (1970), amending Securities Act of May 27, 1933, ch. 38, \& 4(1), 48 Stat. 77. Section $4(1)$ of the 1933 Act, pertaining to private offerings, was renumbered $\S 4(2)$ by the Act of Aug. 20, 1964, Pub. L. No. 88-467, § 12,78 Stat. 565, 580, and declares:

The provisions of section 77e [barring unregistered securities from interstate commerce and the mails] shall not apply to

(2) transactions by an issuer not involving any public offering.

3. 15 U.S.C. $\$ 771$ (1970):

Any person who-(1) offers or sells a security in violation of $\S 77$ e of this title... shall be liable to the person purchasing such security from him, who may sue . . . to recover the consideration paid for such security with interest thereon, less the amount of any income received thereon, upon the tender of such security, or for damages if he no longer owns the security.

4. 308 F. Supp. at 614.

5. 440 F.2d 631,633 . 
The legislative intent underpinning the 1933 Act is aptly summarized by its preamble:

An Act to provide full and fair disclosure of the character of securities sold in interstate and foreign commerce and through the mails, and to prevent frauds in the sale thereof, and for other purposes."

While the Act releases several types of transactions from its registration requirements, one of the most significant classifications exempted has been the private offering. ${ }^{7}$ Private offerings were left undefined in the legislation, although the historical background of the Act suggests that this exemption was primarily intended to cover transactions involving a few insiders having a close relationship to a company in its early development. ${ }^{8}$ Others making frequent use of the private offering have been banks, mutual funds, and insurance companies. ${ }^{9}$ In recent years the increased use of the private placement to obtain venture capital and equity financing ${ }^{10}$ has resulted in a series of cases and SEC releases that have hammered out the contours of the exemption."1

The landmark case outlining the requirements of the private placement exemption was $S E C$ v. Ralston Purina Co., ${ }^{12}$ in which the Supreme Court held that a company's sale of its stock to some five hundred employees failed to qualify for the exemption. Ralston had claimed that it was engaged in a private placement because it limited its offer to certain "key employees," defining them not by position on the organizational chart, but rather in terms of promotion potential, influence among their peers, and sympathy to management. ${ }^{13}$ The Court rejected Ralston's standard and supplied one of its own:

6. 48 Stat. 74 (1933).

7. Steffen, Private Placements Should Be Registered, 43 N.C.L. Rev. 548, 549 (1965):

[T] he dollar value of industrial issues placed privately ... has exceeded that of the

issues registered and sold publicly in every year since 1942.

See also Cohan, Should Private Placements Be Registered?, 43 N.C.L. Rev. 298, $301-06$ (1965).

8. NeW York CITY PRACTICING LAW INSTITUTE, FIRST ANNUAL INSTITUTE ON SECURITIES Regulation 22 (R. Mundheim, A. Fleiseher, Jr. \& D. Glazer eds. 1970) [hereinafter cited as PL1].

9. PLI 22; Cohan, supra note 7, at 309.

10. PL1 22. The practice grew up in the 1950's and 1960's.

11. See Securities Act Release No. 4552 (Nov. 6, 1962), 1 CCH FEd. SEC. L. REP. II 2770, for a discussion of the factors used by the SEC in determining whether an offer qualifies for the exemption. See also Shimer v. Webster, 225 A.2d 880, 882-85 (D.C. Dist. Cl. App. 1967), for a discussion of several leading cases.

12. 346 U.S. 119 (1953).

13. Id. at 121-22. Their reluctance to define "key employees" in terms of their organizational chart was understandable in view of the fact that the employees participating included chow-loading foremen, bakers, and stenographers. 
The natural way to interpret the private offering exemption is in light of the statutory purpose. Since exempt transactions are those as to which there is no practical need for the bill's application, the applicability of $\S 4(\mathrm{I})$ should turn on whether the particular class of persons affected needs the protection of the Act. An offering to those who are shown to be able to fend for themselves is a transaction not involving a public offering."

Apparently in an effort to clarify this classification scheme, the Court suggested that an offering restricted to highly placed executives might be considered a private placement. Yet where the offerees' positions did not afford them regular access to the sort of information which would be disclosed by registration, they must be provided with such information. ${ }^{15}$ The Court rejected any rule-of-thumb number as a basis for classifying an offering, but conceded that the SEC might find "some kind of numerical test" useful in determining which claims to investigate. ${ }^{16}$ Judicial construction, ${ }^{17}$ administrative interpretation, ${ }^{18}$ and scholarly analysis ${ }^{19}$ of the $R$ alston standard have been plentiful and, occasionally, biting. ${ }^{20}$ In describing the requirements of the private offering, the Court introduced, but left

14. Id. at 124-25.

15. Id. at 125-26. See United States v. Custer Channel Wing Corp., 376 F.2d 675, 678 n.2 (4th Cir.), cert. denied, 389 U.S. 850 (1967), for a list of such information.

16. 346 U.S. at 125. See also 1 L. Loss, SECuRITIES REgulation 664 (2d ed. 1961):

[1]t seems relatively safe to assume that an offering to not more than twenty-five persons will be considered exempt-at least so far as Commission intervention as distinct from civil liability under $\S 12(1)$ is concerned. . . .

17. Shimer v. Webster, 225 A.2d 880, 882-85 (D.C. Dist. Ct. App. 1967), discusses the facts and holdings in five other leading post-Ralston cases.

18. See note 11 supra. See also SEC Release No. 5121 (Dec. 30, 1970), 1 CCH FED. SEC. L. REP. If 2784, at 2687; SEC Release No. 7935 (Aug. 10, 1966), [1966-67 Transfer Binder] CCH Fed. SEC. L. Rep. If 77,402, at 82,712; SEC Release No. 7000 (Jan..23, 1963), [196164 Transfer Binder] CCH FED. SEC. L. REP. If 76,895, at 81,306. See generally 1 CCH FED. SEC. L. REP. II 7 2707-2850, at 2673-2702.

19. See generally 1 L. Loss, supra note 16, at 653-87; Harrison, Thirty-Eight Years Without Definition-The Private Offering Exemption, 24 ARK. L. REv. 417 (1971); Orrick, Some Observations on the Administration of the Securities Laws, 42 MiNN. L. REv. 25 (1957); Orrick, Non-Public Offerings of Corporate Securities-Limitations on the Exemption Under the Federal Securities Act, 21 U. PrTr. L. REY. 1 (1959); Victor \& Bedrick, Private Offerings: Hazards for the Unwary, 45 VA. L. Rev. 869 (1959). See the following case notes for initial reactions to Ralston: 4 CATH. U.L. REV. $70-73$ (1954); 52 MiCH. L. REV. 298-300 (1953); 48 Nw. U.L. REv, $771-77$ (1954); 21 U. ChI. L. REv. 113-18 (1953); 3 UtAH L. REv. 519-21 (1953).

20. See, e.g., Israels, Some Commercial Overtones of Private Placement, 45 VA. L. Rev. 851, 852-53 (1959) (accusing the Court of definitional vagueness). See also Sargent, Private Offering Exemption, 21 Bus. LAw. 118, 119-20 (1965):

[A]nybody that has been through the registration process . . . knows full well that no matter what information an issuer may supply to any investor, absent registration, it could not possibly be comparable to that which comes out of the registration process. 
undefined, the investors who are "able to fend for themselves" and the concept of "access." Reference to the former has opened the door to the argument that where sophisticated investors are the offerees, the exemption is satisfied. ${ }^{21}$ The problem of access has usually been resolved by examining the relationship between the parties for evidence that the offeree has had a reasonable opportunity to discover sufficient information about the offering company to permit an intelligent investment decision. ${ }^{22}$ The relationship between access and sophistication has been treated in several ways by the courts. ${ }^{23}$ It has been held that sophisticated investors, particularly institutional ones, have sufficient bargaining power to extract from the issuer all of the information required to make an intelligent investment decision. ${ }^{24}$ It has also been suggested that the putative private offeree must either be sophisticated or he must be afforded access to such information as would be revealed by a registration statement. ${ }^{25} \mathrm{~A}$ third interpretation has required that the investor in a private placement be granted access to such information no matter how sophisticated he might be. ${ }^{26}$ All three interpretations are possible readings of Ralston, but the third one, strictly construed, could seriously erode the utility of the private placement. The first and second views merely echo the Supreme Court's suggestion that those investors who are sophisticated can and do fend for themselves, and therefore do not need the protection of the Act. If, on the other hand, the third interpretation is the correct statement of the law, then companies wishing to make use of private offerings must prepare and submit to all prospective purchasers, even including large institutional investors, most of the information which would have been contained in the very registration statement whose "flyspecking"27 rigors they were trying to avoid.

21. This argument was successfully urged in Value Line Fund, Inc. v. Marcus, [1964-66 Transfer Binderl CCH FED. SEC. L. REP. If 91,523, at 94,970 (S.D.N.Y. 1965), but was rejected in United States v. Custer Channel Wing Corp., 376 F.2d 675, 678 (4th Cir. 1967).

22. See Garfield v. Strain, 320 F.2d 116, 119 (10th Cir. 1963) for a detailed discussion of factors tending to show a close relationship, and as a result, access to necessary information.

23. PLI 40 n.32.

24. See, e.g., Value Line Fund, Inc. v. Marcus, [1964-66 Transfer Binder] CCH FED. SEC. L. REP. If 91,523, at 94, 970 (S.D.N.Y. 1965).

25. See, e.g., Nicewarner v. Bleavins, 244 F. Supp. 26I, 265 (D. Colo. 1965). 1967).

26. See, e.g., United States v. Custer Channel Wing Corp., 376 F.2d 675, 678 (4th Cir.

27. Sargent, supra note 20 , at 120 . See note 20 for the view that nothing short of registration satisfies the Ralston standard. See also PLI 42 for an example of misuse of information released in support of a private placement, and Steffen and Cohan, supra note 7, for an exchange of broadsides as to whether the public interest would be better served by rcgistration of all securities, or whether the Act should be re-written to protect only those who seek its protection. 
The Court of Appeals for the Tenth Circuit held, in Lively v. Hirschfeld, that the Ralston definition of a private group embraced only persons having exceptional business experience and having positions giving them regular access to all data necessary to determine the status and potential of the corporation..$^{28}$ The court noted that the defendants had put only one of the plaintiff-offerees on the stand, an airline pilot with "considerable business experience," who had been an occasional purchaser of stocks. ${ }^{29} \mathrm{He}$ had been given some information about the corporate structure of Wun Drop, but by no means as much as would have been revealed by a registration statement. The other purchasers did not take the stand, but according to defense testimony, they were educated friends and acquaintances of some business background who had received some information about the company. ${ }^{30}$ The court found that even the most sophisticated and best informed purchaser, the pilot, lacked either the exceptional degree of investment experience or the regular access to information about the company-both of which it read Ralston to require. That the other purchasers did not pass this new conjunctive test followed easily.

Although it is too soon to say what Lively $v$. Hirschfeld's exact effect on the private placement exemption will be, the loophole from registration provided by the private offering may now be smaller. The requirement that the private offeree both be exceptionally experienced and have regular access is on its face more stringent than the standards of at least two other circuits. In Gilligan, Will \& Co. $v$. $S E C^{31}$ the second circuit's construction of private offering requirements did not mention sophistication as a requirement at all; the decision was bottomed solely on the issue of access. ${ }^{32}$ In United States v. Custer Channel Wing Corp., ${ }^{33}$ the fourth circuit held only that sophistication was no substitute for access, failing to deal with the issue of the unsophisticated investor. ${ }^{34}$ The rationale of Lively may have arisen from reading the Ralston and Custer standards in combination. The argument proceeds in three steps. If "[a]n offering to those who are shown to be able to fend for themselves is a transaction not involving a public offering,"35 then, arguably, an

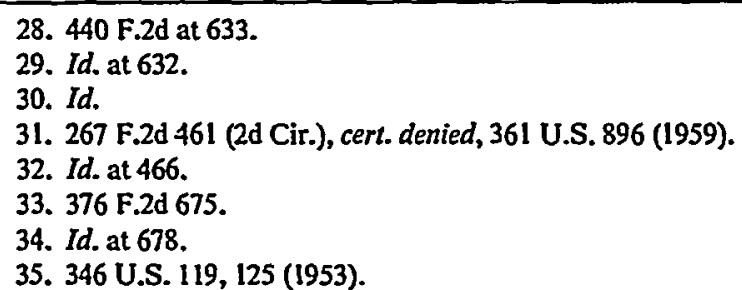


offering to the unsophisticated is ipso facto public. But if Custer is taken literally, then there must be complete access for even the sophisticated investor. Private offerings, therefore, cannot be made to anyone who is not sophisticated and fully informed of the financial condition of the issuing company. It is submitted that this line of reasoning, with its implication that the issuer has the duty to assume the initiative of fully informing all prospective customers-no matter how sophisticated-is of questionable validity. A sounder holding was reached in Value Line Fund, Inc. v. Marcus, ${ }^{36}$ in which a large mutual fund, after suffering sharp losses, sought rescission of a purchase of unregistered stock. The Value Line Fund argued, as did the plaintiffs in Lively, that they did not have sufficient access to the company's records to make an informed investment decision. The court's rejection of this argument was emphatic: "[T]he offerees possessed enough sophistication to demand and enough leverage at the bargaining table to receive" ${ }^{\prime 37}$ sufficient information. Failure to investigate adequately was not to be "twisted into any valid claim that the plaintiffs did not have access to information, or were not in a position to fend for themselves." 38 The court added that an insistence that all offerees in a private placement have positions affording them access to corporate records might shut off the offering to all but the issuer's key employees, thus excluding institutional investors altogether. ${ }^{39}$ An alternative equally disheartening to the issuing company would be to force it to prepare and submit constantly updated prospectuses, replete with the details required for public offerings, to all prospective purchasers. The pragamatism of the Value Line approach to what really goes on in the private placement market is consistent with the Supreme Court's strong suggestion in Ralston that sophisticated investors do not need the protection of the Act. Lively's conjunctive requirement of sophistication and access would totally exclude all unsophisticated investors, even unsophisticated key employees, from private offerings, no matter how much they might know about the issuing company. As for the experienced investors, the drawbacks to Lively's insistence that they have full access to such information as would accompany a registered offering have been noted. What Value Line makes clear 1965).

36. [1964-66 Transfer Binder] CCH FeD. SEC. L. ReP. I 91,523, at 94,970 (S.D.N.Y.

37. Id.

38. Id.

39. Id. 
is that the tenth circuit's protection of experienced investors is not only bothersome, but unnecessary, since it extends the protective wings of Custer and Ralston over sophisticated institutional investors as well as those naive individuals making their first purchase of securities.

Lively $v$. Hirschfeld also raises some troublesome definitional questions in an area of law already justly criticized for its murky language. ${ }^{40}$ Is the tenth circuit's requirement that investors in private placements be "exceptionally experienced" synonymous with "sophisticated," or is it more stringent? Moreover, at what point in his career does an investor leave the zone of "considerable experience" of the airline pilot in Lively and reach the area of "exceptional experience" required by the tenth circuit? These distinctions may not be as significant as they first appear, inasmuch as the court may have meant only that the purchasers before it were not sophisticated enough to fend for themselves, but whether real or imagined, this apparent shift in classification is likely to raise more questions than it answers. A former commissioner of the SEC, discussing abuses of the private offering exemption, observed that "to a certain extent some chickens have been getting under the fence in recent years." 41 The tenth circuit, by hardening its tone, and perhaps altering its requirements, may be attempting to do nothing more than mend that fence. Nevertheless, by strengthening the gloss put on Ralston by Custer, and by its use of somewhat ambiguous language, the opinion in Lively $v$. Hirschfeld may be remembered more for its in terrorem effects on would-be issuers of unregistered securities than for its predictive value.

40. See note 20 supra.

41. Sargent, supra note 20 , at 118. 
. 